\title{
La independencia del Poder Judicial durante la Dictadura de Primo de Rivera (1926-1930) \\ y el epílogo de los gobiernos Berenguer y Aznar-Cabañas (1930-1931): \\ Deterioro evidente*
}

\section{The independence of the Judicial Power during the Primo de Rivera Dictatorship (1926-1930) and the epilogue of the Berenguer and Aznar-Cabañas governments (1930-1931): An evident Deterioration}

Emilio Javier DE BENITO FRAILE

Profesor Titular de Historia del Derecho

Departamento de Historia del Derecho

Facultad de Derecho. Universidad Complutense de Madrid emibe@der.ucm.es

Recibido: 7 de septiembre de 2015

Aceptado: 30 de octubre de 2015

\section{RESUMEN}

Los avances logrados en la Independencia del Poder Judicial durante los primeros momentos del Directorio de Primo de Rivera, van a ir decayendo progresivamente, acentuándose en la etapa (1926-1930). El examen de este último periodo constituye el objeto de este trabajo; en el que se analiza tanto la producción normativa, como la actitud despótica manifestada por el Ejecutivo en el desarrollo y aplicación de la misma.

PALABRAS CLAVE: Directorio Primo de Rivera, Independencia del Poder Judicial, regulación legal, intromisiones del Gobierno en el desarrollo y aplicación de la misma.

\footnotetext{
ABSTRACT

The advances achieved in the Independence of the Judicial Power during the first moments of Primo de Rivera Directory, were progressively declining, and very fast so in the stage 1926-1930. The examination

* Trabajo realizado en el seno del proyecto de investigación Control y responsabilidad de los jueces: una larga experiencia (DER 2013-44216-P).
} 
of the latter period constitutes the object of this work, which analyses both the normative production, and the despotic attitude showed by the Executive in the development and application of these laws.

KEYWORDS: Primo de Rivera's Directory, Judicial Power Independence, legal regulation, interferences of the Government in the development and application of the legislation.

\section{RÉSUMÉ}

Les progressions obtenues dans l'Indépendance du Pouvoir Judiciaire durant les premiers moments du Directoire de Primo de Rivera, vont tomber progressivement en déchéance, surtout dans l'étape de 19261930. L'examen de cette dernière période constitue l'objet de ce travail, dans lequel la production normative est analysée aussi bien que l'attitude despotique manifestée par l'Exécutif dans le développement et l'application de cette legislation-là.

MOTS CLÉ : Directoire de Primo de Rivera, indépendance du Pouvoir Judiciaire, régulation légale, intromissions du Gouvernement dans le développement et l'application de la legislation.

SUMARIO: 1. Introducción. 2. Desarrollo legislativo. 3. Espíritu que caracterizó la actuación práctica del Ejecutivo frente a la magistratura. 4. Conclusiones.

\section{Introducción}

A lo largo de la Dictadura de Primo de Rivera, la magistratura española pasa principalmente por dos etapas diferenciadas. Una primera que coincidiría con el periodo que transcurre desde el pronunciamiento militar hasta junio de 1926, en la que a la cabeza del Poder Judicial se encuentra la Junta Organizadora del Poder Judicial, creada en $1923^{1}$, y un segundo periodo que se inicia a partir de la mencionada fecha (junio de 1926), momento en que la citada Junta se disuelve para dar paso a un nueva organización judicial, en la que el Consejo Judicial se constituye como el nuevo órgano supremo de la judicatura, y que pervivirá hasta la finalización de este régimen político (incluido los gobiernos de Berenguer y Aznar-Cabañas), para ser disuelto por el nuevo constituido con la proclamación de la II República. Será a este segundo periodo (1926-1931), al que me referiré en este estudio, incidiendo, de nuevo, tanto en la producción legislativa, como en su aplicación en la práctica ${ }^{2}, \mathrm{y}$ en definitiva en

\footnotetext{
${ }^{1}$ Para todo lo relativo a este periodo, ver, mi art. "La independencia del Poder Judicial durante la Dictadura de Primo de Rivera (1923-1926). ¿Realidad o ficción?”, Anuario de Historia del Derecho Espanol, (en adelante $A H D E$ ), LXXXV, 2015, pp. 347-375. En el mismo denunciaba las dificultades puestas por parte de los responsables del Archivo del Tribunal Supremo para la consulta de los fondos que allí se encontraban depositados. Al igual que en aquel momento quise hacer públicos tales comportamientos, creo que es de justicia destacar la colaboración que estoy encontrando en estos momentos con el nuevo equipo, y muy especialmente con su directora, Doña Teresa de Arriba Fernández, quien me facilita, en todo lo que puede, el acceso a la documentación requerida. Vaya por delante mi reconocimiento al cambio de actitud de los nuevos responsables y mi sincero agradecimiento a los mismos.

${ }^{2}$ Los documentos de aplicación del derecho correspondientes a este periodo son escasamente expresivos, al tratarse, en la mayor parte de los casos, de documentación oficial, procedente del Consejo, en la que,
} 
el papel que jugaron ambas vertientes en la consecución o no de una mayor independencia del Poder Judicial.

\section{Desarrollo legislativo}

Tal y como señalo anteriormente, con fecha 21 de junio de 1926, se promulga un Real Decreto por el que se crea el Consejo Judicial ${ }^{3}$. En su art. $1^{\circ}$, y como consecuencia del establecimiento del nuevo organismo que comenzaría a funcionar el 1 de julio, quedaban disueltas la Junta Organizadora del Poder Judicial y la Inspección central de la Administración de Justicia, cuyas atribuciones y facultades asumiría aquel; quedando constituido como el órgano superior del Poder Judicial en el orden gubernativo y disciplinario, salvo el Tribunal Supremo en pleno o la Sala de Gobierno del mismo, en cuanto fuera de la exclusiva competencia de éstos, y dependiendo, a efectos de organización y funcionamiento, del Ministerio de Gracia y Justicia ${ }^{4}$.

Las razones que justificaban las reformas aparecen expresamente señaladas en la exposición de motivos, donde se alude a la necesidad de poner fin, a aquellas circunstancias que habían impedido la consecución de los loables objetivos perseguidos con la creación de la citada Junta Organizadora del Poder Judicial. Entre las mismas se mencionan "los peligros de someter al sufragio de funcionarios diseminados por todo el país la designación de los que en lo sucesivo hubieran de resolver sobre sus destinos", provocando, según sus términos, verdaderas luchas electorales; "o el hecho

como es lógico, se limitan a resolver sin dar cabida a cualquier otro tipo de consideraciones. Además, las nuevas formas de designación de la cúpula judicial establecidas en esta etapa permitían poco margen a las desafecciones. Esto nos ha llevado a tener mayores dificultades a la hora de analizar la práctica cotidiana y las relaciones gobierno-magistratura. Dicha escasez de datos proporcionados por este tipo de documentación, la hemos tratado de suplir con otro tipo de fuentes, como son: las noticias publicadas por los periódicos (aunque censurados), las informaciones facilitadas por los autores del momento y en definitiva por todos aquellos medios a nuestro alcance. El análisis conjunto de todos ellos, creo que nos han permitido esbozar con bastante aproximación el panorama que caracterizó las relaciones Poder Ejecutivo-Poder Judicial en el periodo tratado.

${ }^{3}$ Organismo que ya había sido constituido por Real Decreto de 15 de mayo de 1917, pero que no llegó a funcionar, al ser suprimido un mes después por un nuevo Real Decreto. Tal y como se señala en la exposición de motivos del Real Decreto de 1926, con este último se trata de suplir todo aquello que llevó a la inoperancia del anterior "siendo sus características diferenciales del que tan efímera vida logró, de una parte, la de que no le falta lo que se alegó para derogarle, o sea la atribución de velar por el decoro de los funcionarios judiciales y eliminar entre éstos a aquellos acerca de los cuales adquiera la convicción moral de no ser dignos de seguir perteneciendo a carrera tan prestigiosa, y de otra, la de prescindir para integrarlo de personas respetabilísimas, pero ajenas a la Magistratura, a las que antes se acudió, confiando sólo a funcionarios de su propio seno la depuración más acabada, conforme al elevado espíritu que inspiró los inolvidables Decretos Directoriales de 3 y 20 de Octubre de 1923" También mediante R1. Decreto de la misma fecha se establece la separación orgánica de las carreras judicial y fiscal, regulando su misión, atribuciones, organización y planta, deberes, derechos y honores de los funcionarios del Ministerio Fiscal y la unidad y dependencia del mismo.

${ }^{4}$ Así como, Art. 1 del Reglamento promulgado el 22 de noviembre de ese mismo año. 
de que funcionarios de categorías inferiores decidan los ascensos de los de las categorías superiores". Son varios los autores que corroboraban tales circunstancias, como grandes males que afectaban al funcionamiento de la Junta y que constituyeron el germen de su desaparición ${ }^{5}$.

El nuevo Consejo estaba integrado por el Presidente del Tribunal Supremo, que lo era del Consejo, los presidentes de Sala del mismo (siempre que fueran de la carrera), el magistrado más antiguo en la categoría y el de mayor tiempo de servicios en cargos judiciales o fiscales que pertenecieran al mismo Tribunal, el presidente de la Audiencia Territorial de Madrid y el juez de primera instancia Decano de dicha ciudad. El resto, hasta completar el número de nueve miembros, serían designados libremente entre los funcionarios de la carrera judicial con destino permanente en Madrid por Real Decreto acordado en Consejo de Ministros, a propuesta del de Gracia y Justicia ${ }^{6}$. El consejero más antiguo, era considerado Vicepresidente, sin necesidad de nombramiento expreso ${ }^{7}$. Para la deliberación y adopción de acuerdos, se establecía la concurrencia de al menos cinco de sus miembros y la mayoría absoluta ${ }^{8}$. Eran atribuciones del Consejo: velar por el prestigio de los Tribunales y Juzgados y de los magistrados y jueces; velar por su buena forma y vindicarla cuando fuese injustamente atacada; premiar los actos meritorios, castigar aquellos otros contrarios a la función y a la integridad personal, constituyéndose, a este último efecto, en Tribunal

\footnotetext{
${ }^{5}$ J. Montero Aroca, Independencia y responsabilidad del Juez, Madrid, 1990, p. 80, E. Pedraz Penalva, Constitución, Jurisdicción y Proceso, Madrid, 1990, p. 83, R. Rubio, "La Inspección de los Tribunales", Anuario de Derecho Civil, Madrid, 1949, pp. 30 y 32.

${ }^{6}$ Art. 2 y art. 2 y 3 del Reglamento. La primera composición del Consejo estuvo integrada por los siguientes señores: Presidente: Don Andrés Tornos Alonso, Presidente del Tribunal Supremo. Conseje-

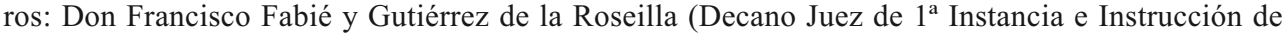
Madrid), Don Rafael Bermejo y Ceballos Escalera (Presidente de la Sala $1^{\text {a }}$ del Tribunal Supremo), Don José María de Ortega y Morejon (Magistrado del Tribunal Supremo y actual Inspector Central de Tribunales, de obligada preferencia), Don Antonio Satiuste y Ubeda (Presidente de la Audiencia Territorial de Madrid), Don Bernardo Longue y Mariategui (Magistrado del Tribunal Supremo con más años de servicio entre los procedentes de las carreras judicial y fiscal y actualmente Presidente de la Junta Organizadora del Poder Judicial e Inspector Central de Tribunales), Don Francisco García Goyena y Alzugaray (Magistrado del Tribunal Supremo más antiguo de la categoría entre los procedentes de las carreras judicial y fiscal), Don José García Valdecasas (Magistrado del Tribunal Supremo y actual Inspector Central de Tribunales, de obligada preferencia) y Don Luis Ibarguer y Pérez Seoane (Magistrado del Tribunal Supremo, actual vocal de la Junta Organizadora del Poder Judicial, de obligada preferencia). Secretarios: Don Aurelio Artacho Navarrete (vocal propietario de la Junta Organizadora del Poder Judicial), Don Gustavo Lescure Sánchez (vocal propietario de la Junta Organizadora del Poder Judicial), Don Luis Felipe Vivanco y Pérez del Villar (actual Inspector Secretario de la Junta Inspectora Central), Don Domingo Cortón Freijanes (actual Inspector Secretario de la Junta Inspectora Central) y Don Antonio Delgado Curto (actual Inspector Secretario de la Junta Inspectora Central), quien actuaría como Secretario General del Consejo. Archivo Tribunal Supremo (en adelante ATS), Leg. 9.228B, Exp. 2.129

${ }^{7}$ Art. 3 y art. 3 del Reglamento.

${ }^{8}$ Art. 3 del Rl. Decreto y 4 del Reglamento.
} 
de Honor'; correspondiendo al Gobierno los nombramientos y ascensos en todas las categorías, aunque se confiaba al Consejo la declaración de aptitud ${ }^{10}$.

En el presente Real Decreto se emplazaba al Consejo Judicial para redactar su reglamento de funcionamiento con anterioridad al 31 de octubre próximo ${ }^{11}$. Efectivamente, con un mínimo retraso con respecto a la fecha establecida, el 22 de noviembre quedaba aprobado el citado Reglamento.

La valoración de las nuevas medidas fue muy diversa. Así para Ponte Escartín, sería muy favorable, como no podía ser de otra forma, al tratarse del autor de las mis$\operatorname{mas}^{12}$. En un sentido positivo se pronuncia, asimismo, Aguilar, quien señala "La constitución del Consejo Judicial ha de ser considerada como valiosísima y eficacísimo avance en el perfeccionamiento de la Administración de Justicia"13. Contrariamente a las apreciaciones anteriores, José Lizcano consideraba la creación del nuevo órgano como un gran retroceso en la independencia judicial "disolvió aquella y constituyó en su lugar un Consejo Judicial, cuya composición revelaba una clara influencia ministerial y cuyas atribuciones, muy amplias ciertamente, no pasaban de lo meramente informativo"14. En parecidos términos se pronuncia Antonio Fuentes "Un decreto de 21 junio la sustituyó por un Consejo Judicial que minimizaba la dirección de la Magistratura en beneficio del poder ejecutivo" ${ }^{15}$. De forma destacada, su configuración como Tribunal de Honor, fue duramente criticada por los autores, por las consecuencias que

\footnotetext{
${ }^{9}$ Art. 12-16 del R1. Decreto y 44 del Reglamento. Este último aspecto resultaba peligrosísimo, entre otras razones, tal y como señala $\mathrm{M}^{\mathrm{a}}$ Inmaculada Sánchez Barrios, "por el corporativismo que implicaba, por la falta de garantías procesales para el sometido al mismo, por los indeterminados y subjetivos criterios que servían de referencia para adoptar las decisiones, por cuanto fomentaba el servilismo y la dependencia, etc", en "Consejo del Poder Judicial", Revista del Poder Judicial, 46 (segundo trimestre 1997), nota 45.

${ }^{10}$ Art. 20. Por Circular de 15 de marzo de 1927, el presidente del Consejo ordenó a los presidentes de las Audiencias que cada año enviaran informes sobre todos y cada uno de los jueces y magistrados del territorio. Para Montero Aroca, esta medida supondría el inicio de los informes reservados, en op. cit., p. 81. ${ }^{11}$ Art. 25.

${ }^{12}$ «Por mi parte, he hecho lo posible incluyendo en el Decreto orgánico del Consejo Judicial el art. 20 y en el Estatuto Fiscal el art. 30....que han ennoblecido notoriamente los procedimientos de petición. Y ahora, por iniciativa del Jefe del Gobierno ... se han llevado al nuevo Código Penal sanciones como las de los artículos 425 y 814 para castigar las recomendaciones, sobre todo en asuntos judiciales. Esos nuevos preceptos aplicados con rigor han de sanear las costumbres y han de enaltecer los prestigios de la Magistratura, contribuyendo a lograr la ansiada total independencia de ésta», en Discurso leído por el Excmo. Sr. D. Galo Ponte Escartín, Ministro de Gracia y Justicia en la Solemne apertura de los Tribunales, celebrada el 15 de septiembre de 1928”, Ed. Reus, Madrid, 1928, p. 107.

${ }^{13}$ Aguilar, A., De la administración de la Justicia. (Innovaciones efectuadas durante el último trienio), Revista de Derecho Privado, T. XIII, (1926), p. 364.

${ }^{14}$ J. Lizcano Cenjor, "Independencia Judicial”, Revista Derecho Judicial, (julio-septiembre 1961), p. 149. Manifestándose, asimismo, muy crítico con el art. 20 del citado Rl. Decreto, "dentro de un tremendo art. 20", p. 150.

${ }^{15}$ A. Fuentes Pérez, "El Principio de la Independencia", Revista de Derecho Judicial, 40 (octubre-diciembre, 1969), p. 134.
} 
ello implicaba. Este es el caso de Salazar Alonso, conocido crítico con el gobierno, quien nos habla de "Tribunal de la Santa Inquisición", de desaparición de las garantías establecidas por la ley, o de "razzia" contra los jueces ${ }^{16}$, o Pedraz Penalva, para quien resultaba peligrosísimo este funcionamiento del Consejo Judicial ${ }^{17}$.

En su afán renovador, Ponte Escartín, continúa promulgando nuevas disposiciones para la consecución de lo que en sus palabras constituirá "no la reforma de la administración de justicia, sino la revolución de la justicia"18. Reformas que en su conjunto conducirán a una mayor intervención del poder ejecutivo en los asuntos judiciales y consecuentemente una pérdida del grado de autonomía del Poder Judicial, logrado en la anterior etapa de la Dictadura, contrariamente a lo expresado en los discursos retóricos pronunciados por el artífice de las mismas ${ }^{19}$.

Un claro reflejo de estas aspiraciones gubernamentales lo encontramos en el Real Decreto-Ley de 14 de octubre de 1926, por el cual el Consejo de Ministros, con carácter extraordinario, podría acordar la suspensión de las sentencias declaradas firmes de la Sala Tercera del Tribunal Supremo o de los Tribunales provinciales contenciosoadministrativos. Facultad que se ve ahora ampliada, además de a los supuestos ya establecidos, a aquellos en que se estime que la resolución administrativa, objeto del recurso y revocada o modificada por la sentencia, fue dictada con el fin de moralizar la Administración ${ }^{20}$, añadiendo además, que no procederá la acción para solicitar la indemnización, en aquellos casos en que el Gobierno hubiera acordado la suspensión o inejecución de la sentencia ${ }^{21}$. La aprobación del citado Real Decreto-Ley fue objeto de una enconada discusión en el seno del Consejo de Ministros, según señala Calvo Sotelo, miembro del Consejo, "Y de ahí ese Decreto, objeto de empeñadísima discusión en el seno del Consejo"22.

\footnotetext{
${ }^{16}$ Como ya he indicado anteriormente, este autor se caracterizó por liderar una crítica feroz, siempre que pudo, contra el régimen político imperante. De ahí su juicio negativo con respecto a las reformas y su incidencia en la administración de justicia "El juez o magistrado vivirá siempre en zozobra. La tranquilidad que requiere el ejercicio de tal alta función como administrar justicia, se ahuyentará del espíritu", en La Justicia Bajo la Dictadura, Madrid, 1930, pp. 88-90.

${ }^{17}$ E. Pedraz Penalva, Constitución; Jurisdicción y Proceso, Madrid, 1990, p. 84.

${ }^{18}$ Diario de Sesiones de la Asamblea Nacional, Sesión de 13 de Diciembre de 1928. p. 220. "si el Marqués de Estella, a su vez, sigue depositando su confianza en mí, yo anuncio, expresa, categóricamente, que no en el año 1929, sino en el primer semestre de 1929 se realizará, no la reforma de la administración de Justicia, sino la revolución de la Justicia, que aquí tanto se nos pide".

${ }^{19}$ Para J. Lizcano Cenjor, no deja de ser una nueva paradoja del régimen dictatorial "en dicha fecha al Directorio Militar le había sustituido un sistema de Departamento ministeriales y al frente del de Gracia y Justicia: Don Galo Ponte Escartín, que figuraba en el Escalafón de la carrera judicial y fiscal", en op.cit., p. 149.

${ }^{20}$ Art. 1.

${ }^{21}$ Art. 3.

${ }^{22}$ A. Agúndez, Historia del Poder Judicial en España, Madrid, 1974, p. 168. Para Agúndez, se trata de una ley que revela la debilidad sentida por el Gobierno que, poderoso en sus orígenes, iba perdiendo las fuerzas que le dieron nacimiento, en op.cit., p. 167. También Quintiliano Saldaña se pregunta “¿Cómo
} 
La aprobación del citado Real Decreto-Ley tuvo, asimismo, un seguimiento en la prensa del momento, en la que en "nota oficiosa", se aludía al malestar generado en la magistratura las nuevas medidas adoptadas, lo que había provocado que los magistrados de la Sala Tercera prefirieran quedar excedentes a seguir actuando ${ }^{23}$. Información que motivó que el propio ministro procediera a desmentir tal noticia, y dirigir al presidente del Tribunal Supremo una Real orden encaminada a acreditar por los propios interesados si era real la existencia de tales peticiones de excedencia. La respuesta del Presidente del Alto Tribunal no se hizo esperar y con fecha 21 de ese mismo mes, contesta negando la misma y manifestando su constatación de que los señores magistrados "no abrigan otros propósitos con relación a su cometido que el de cumplir fiel y lealmente sus deberes, como siempre quisieron y entendieron hacerlo, y el de acatar las disposiciones legales"24. El mero hecho de que tales extremos fueran difundidos en los medios de comunicación, nos hace pensar como altamente probable la existencia de un malestar entre la magistratura, que en definitiva observaba como se limitaba la eficacia de sus resoluciones judiciales.

La batería de nuevas reformas continua. El ministro Ponte Escartín no se da tregua para conseguir lo que él calificaba de Revolución de la Justicia. A lo largo del año 1927, se procedió a establecer una nueva organización del Tribunal Supremo mediante Real Decreto-Ley de 15 de agosto. En esta misma fecha se implantó también mediante Real Decreto-Ley nuevas normas de organización de la carrera judicial ${ }^{25}$, en las que continuaba el Ministro de Gracia y Justicia conservando de su exclusiva

el día en que apareció en la Gaceta ese Decreto, no presentaron su colectiva dimisión todos los magistrados de la Sala 3a?", en Al Servicio de la Justicia. La Orgía Áurea de la Dictadura, Madrid, 1930, p. 29. Para L. Calamita, el citado Real Decreto, respondió a la necesidad de luchar contra unas resoluciones adoptadas con independencia, al margen de los intereses gubernamentales, en "Pasando el Rato. Justicia para la Justicia", Revista de los Tribunales, tomo LXV, núm. 36-37, 1931, p. 519. En parecidos términos de manifiesta E. Pedraz Penalva, en op. cit., p. 88.

23 "En el ministerio de Gracia y Justicia se ha dado a la Prensa la siguiente nota: Con un nos dicen en El Sol y con una afirmación rotunda en La Voz, suscrita, respectivamente por el cronista de Tribunales, señor Salazar Alonso y un Interino, se ha publicado la noticia de que bastantes magistrados de la sala tercera del Tribunal Supremo se encuentran aquejados por enfermedades que les obligan a pedir su excedencia. Claro es que con eso lo que se quiere dar a entender es que el reciente Real decreto sobre suspensión e inejecución de sentencias de los Tribunales Contencioso-administrativos ha sentado tal mal a los magistrados de la sala tercera que prefieren quedar excedentes a seguir actuando", en La Epoca, 20 de octubre de 1926. Asimismo se hacen eco de la noticia El Sol y La Libertad, ambos de 21 de octubre de ese mismo año.

${ }^{24}$ La Correspondencia Militar, La Época y La Libertad, de 27 de octubre de 1926.

${ }^{25}$ Se establecía dos clases de funcionarios judiciales: Jueces y Magistrados. Cada una de estas tres clases comprendía tres categorías: entrada, ascenso y término. Art. 1. El ascenso dentro de cada clase no determinaba la traslación del funcionario, salvo si el Ministro, oído el Consejo Judicial, lo estimaba conveniente. Art. 8. Se preveía, asimismo, el traslado «Cuando por el natural decaimiento de facultades físicas que la edad ocasiona, achaques o enfermedades crónicas que necesariamente producen menor rendimiento de trabajo, o por otras circunstancias análogas, resulten las obligaciones de un cargo visiblemente superiores a lo que el Juez o Magistrado que lo desempeñe pueda cumplir», Art. 10. Para Sa- 
competencia la facultad de designar libremente a los Presidentes de las Audiencias Territoriales y provinciales, así como a los Presidentes de Sala y Sección, manteniendo el Consejo Judicial sus atribuciones para calificar la aptitud de los Jueces y Magistrados e informar al Ministro sobre los nombramientos de su competencia ${ }^{26}$. El 22 de ese mismo mes, se promulgó una Real Orden regulando las peticiones de destinos o traslados de Jueces y Magistrados, incluyéndose un sorprendente art. en el que se establecía "que el servicio de información necesario para la más acertada adjudicación de los destinos a los funcionarios tendrá un carácter reservado y correrá directamente a cargo del Jefe de la Sección, sin perjuicio de que los informes sean unidos al expediente personal respectivo" ${ }^{27}$. Regulación, verdaderamente sorprendente, y que como ya señaló de forma acertada en su momento Lizcano Cenjor, "A la vista de esto resulta completamente superfluo haber montado la complicada máquina de un Consejo Judicial, si luego lo más delicado de su función: informes sobre aptitud del personal judicial, va a correr a cargo de un Jefe de una Sección de Justicia, Culto y Asuntos generales del Ministerio de Gracia y Justicia"28.

No había terminado el año, cuando el Ministro volvió a dar un golpe de efecto que le garantizaba la ausencia de elementos incontrolados en los Tribunales. Si ya era de su exclusividad el nombramiento de los Presidentes de las Audiencias Territoriales y Provinciales, así como los Presidentes de Sala y Sección, ahora su objetivo va a ir dirigido al escalafón más bajo de la administración de Justicia. Mediante Real Decreto-Ley de 14 de diciembre establece el cese, a efectos 1 de enero de 1928, de todos los Jueces y Fiscales municipales del territorio español, cualquiera que fuera la fecha de su nombramiento y la fijada para la terminación de sus funciones ${ }^{29}$. El nombramiento de los nuevos jueces y fiscales municipales correspondía a los Presidentes y Fiscales de las Audiencias territoriales, respectivas, a propuesta de los Presidentes y Fiscales de las Audiencias Provinciales (ambos de designación libre del ministro), así como su remoción ${ }^{30}$. Contra tales nombramientos no se otorgaba recurso alguno $^{31}$. Con esta medida alejaba cualquier disidencia en los tribunales inferiores,

lazar Alonso, el citado Real Decreto Ley, deja claras las intenciones del "dictador de la calle de San Bernardo", su obsesión «de dirigir sus tiros contra algunos que no le eran gratos, se percibe ya el designio de facilitar galopantes ascensiones», en La Justicia bajo la Dictadura, Madrid, 1930, pp. 108 y 109.

${ }^{26}$ Arts. 5 y 6.

${ }^{27}$ Art. 10. En aplicación del mismo, ver, Archivo General de la Administración (en adelante $\left.A G A\right),(7)$ 4.2. 41/4573, Exp. 1767.

${ }^{28}$ J. Lizcano Cenjor, op. cit., pp. 150 y 151.

${ }^{29}$ Art. 1.

${ }^{30}$ Arts. 2. 3, 4, 5 y 6. En su aplicación, ver $A G A$, (7) 4.2. 41/4576, Exp. 1.974. Con anterioridad al citado Real Decreto-Ley, y mediante Real Decreto de 7 de Diciembre de 1925, se había resuelto suspender la renovación pendiente de la mitad de los Jueces municipales y sus suplentes y prorrogarlos hasta el 30 de junio de 1926. Prórroga que será ampliada por Reales Decretos de 21 de junio y 17 de diciembre de 1926, afectando este último también a los Fiscales y suplentes.

${ }^{31}$ Art. 7. 
al permitir poder ser reelegidos aquellos que se considerara conveniente, siempre y cuando, como es lógico, concurrieran las circunstancias exigidas ${ }^{32}$. Como ya nos resulta habitual, en la exposición de motivos del citado Real Decreto, se vuelve a insistir en que, aun siendo intenciones del Gobierno alejar la política de la Justicia ${ }^{33}$, no debe por ello autorizar con su inactividad, que representantes de determinados grupos o personalidades dirijan la Justicia municipal, persiguiendo para ello la extirpación de antiguos caciquismos.

Los periódicos del momento, como era habitual, no tardaron en dar noticia de la reforma aprobada. Algunos de ellos, exclusivamente, reproduciendo el reciente Real Decreto promulgado ${ }^{34}$. Otros, publicando en los días sucesivos, dos diferentes "notas oficiosas" enviadas por el propio ministerio, en las que claramente su titular, trata de justificar la medida adoptada. En la primera de ellas, además de pedir que, ante la avalancha de visitas y cartas recibidas "de aspirantes a jueces municipales y de personas que se interesan para que otras determinadas obtengan los cargos", se abstengan de hacerlo; no pierde el Sr. Ponte la ocasión de insistir en las buenas intenciones que le llevaron a promulgar el citado Real Decreto en los términos vistos, resaltando la liberalidad ejercida "Dada la índole del decreto sobre nuevos jueces y fiscales municipales, es evidente que hubiera podido asignarse al ministro la facultad de hacer los nombramientos" ${ }^{\prime 3}$. Los términos en que se expresa el ministro indican claramente la concepción autoritaria que caracteriza los planteamientos del mismo, al margen de las palabras vacías, tan reiteradas en sus discursos y grandes pronunciamientos, sobre la independencia del Poder Judicial. Continua, el titular de Justicia, incidiendo en la "libertad absoluta" dispensada a aquellos a quienes se atribuye los nombramientos, pero "conforme a las instrucciones que les tienen dadas" ${ }^{36}$. Instrucciones, que se detallan y aclaran en la segunda nota, con una redacción un tanto confusa, en la que vuelve a insistir en la bondad de la medida gubernamental "pero muy sincera de lo que el Gobierno se propone lograr con esta renovación, y lo que, como deber de conciencia cumplir, solicita de las personas llamadas a informar y resolver en materia tan fundamental, pues nadie puede ignorar la importancia que tienen para el ejercicio y protección de los legítimos derechos ciudadanos la institución de la justicia muni-

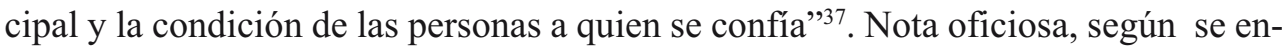

\footnotetext{
${ }^{32}$ Art. 5.

${ }^{33}$ «Y conste, Señor, ya que quedan escritas las palabras precedentes, que el Gobierno quiere alejar totalmente la política de la Justicia municipal, y las Audiencias en pleno podrán atestiguar no haber recibido del Gobierno la indicación más mínima relacionada con los nombramientos que son facultad atribuida a dichos Tribunales».

${ }^{34}$ El Sol, 16 diciembre 1929.

${ }^{35}$ La Voz, 19 de diciembre de 1927 y La Época y El Imparcial, ambos de 20 de diciembre del mismo año.

${ }^{36}$ Ibidem.

${ }^{37}$ La Voz y La Época, ambos de 26 de diciembre de 1927, así como en El Globo de 27 del mismo mes y año.
} 
carga de resaltar el mismo ${ }^{38}$, al permitirse sugerir a los jueces responsables de los nombramientos, los aspectos a considerar para la consecución de una acertada elección: "Han de ser éstas (las personas designadas) de probada rectitud y carácter, honorables en su conducta, capaces, desapasionados y comprensivos, diligentes, cultos y, en lo posible, apolíticos" ${ }^{\prime 39}$; y otorgando, según deducimos por lo confuso del texto, a la Unión Patriótica ${ }^{40}$, dependiente del gobierno, un cierto papel para velar por la pureza de tales designaciones y protagonista de las mismas, al constituirse sus miembros en los más idóneos para los nuevos nombramientos, por ser, mayormente, en ellos, en los que concurren las cualidades indicadas por el Ministro "El Gobierno, que patrocina la vida y formación de la Unión Patriótica, la imagina y la desea como legión nacional y desinteresada y apolítica, inspirada y movida por estímulos de purificación social, donde caben todos los hombres de bien"41. Al margen de la interpretación que hayamos podido hacer de las palabras del ministro, al no resultar, al menos desde nuestro punto de vista, suficientemente claras; de lo que no cabe ninguna duda es de que se está aludiendo a una formación política concreta a la hora de resaltar las cualidades que deben concurrir en los nuevos designados Jueces y Fiscales ${ }^{42}$. Intromisiones externas en los asuntos judiciales que volvemos a observar de nuevo en la reunión celebrada en Barcelona, en la sede de la Capitanía General, para tratar de la renovación de los jueces municipales ${ }^{43}$. Por último, algunos medios publicaron editoriales comentando la nueva disposición aprobada. Este es el caso de El Imparcial, que aplaude las intenciones del Gobierno en cuanto a sus deseos de que se acierte en las designaciones de los nuevos Jueces y Fiscales municipales, pero advierte que la experiencia demuestra que no se debe incurrir en un optimismo anticipado ${ }^{44}$. Más

38 "No era, acaso, materia adecuada al contenido de la disposición oficial; pero si lo es de una declaración oficiosa, poco técnica, acaso...", en Ibidem.

${ }^{39}$ Ibidem.

${ }^{40}$ Sobre la Unión Patriótica, ver: R. Martínez Segarra, "La Unión Patriótica”, Cuadernos de la Cátedra Fadrique Furió Ceriol, ñ 1, Valencia, 1992, pp. 67-75. X. Tusell Gómez, La España del siglo XX. Desde Alfonso XIII a la muerte de Carrero Blanco, Barcelona, 1975, pp. 182-185.

${ }^{41}$ Ibidem.

${ }^{42}$ El decisivo protagonismo de la Unión Patriótica en los Juzgados municipales ya fue destacado por Salazar Alonso, quien se manifestaba de la siguiente forma: «Los caciques se adaptaron a las Uniones Patrióticas, manto protector que, al conjuro del amor a la Patria, purificaba todas las culpas. La Unión Patriótica mandaba y campeaba por sus respetos. Había logrado tener de su seno a los jueces municipales y quería ejercer imperio sobre los de Primera Instancia. Podríamos citar a centenares los traslados de jueces por haber incurrido en el enojo de los monopolizadores del patriotismo...», en op. cit., p. 100. También confirma la intervención de la Unión Patriótica en el nombramientos de Jueces y Fiscales municipales; R. Martínez Segura destaca: «La U.P. formará, a partir de 1927, parte de las Juntas Ciudadanas de Autoridades en todas las provincias, cuya misión será que los elementos del partido formulen observaciones para designar a las personas que ocupan los cargos de jueces y fiscales municipales siempre que estén vinculados a la U.P.», en op. cit., p. 73. Ver también E.J. de Benito Fraile, op. cit.

${ }^{43}$ Reunión presidida por el capitán general y a la que asistieron el gobernador civil, el presidente de la Audiencia, el fiscal de S.M., el presidente de la Diputación, el alcalde y el jefe provincial de la Unión patriótica, en El Imparcial, de 24 de diciembre de 1927.

${ }^{44}$ El Imparcial de 29 de diciembre de 1927. 
crítico con la reforma se manifiesta El Sol, el cual alude al régimen interino de la reforma, para subrayar a continuación que, por otro lado, esta interinidad atenúa los peligros que la propia norma conlleva, como es la posibilidad de que los presidentes de las Audiencias territoriales puedan separar libremente, al igual que nombrar, a los jueces y fiscales municipales, atendiendo a aspectos tan subjetivos como la buena fama o el cumplimiento de los deberes ciudadanos. Amovilidad, que también, según el citado rotativo no contribuirá a la independencia de los citados jueces y fiscales ${ }^{45}$.

La política limitadora de la independencia del Poder Judicial, que caracterizaba al ministerio presidido por Ponte Escartín, se manifiesta de nuevo y de forma contundente en el Real Decreto-Ley promulgado el 22 de diciembre de $1928^{46}$. En el mismo se creaba la "Comisión reorganizadora de la Administración de Justicia", presidida por el propio ministro ${ }^{47}$, pero además se perseguía acabar con la inamovilidad de los jueces. Extremo este último, que se expresa claramente en las intenciones recogidas en la exposición de motivos, donde se dice: "De conveniencia notoria es que, al mismo tiempo que se transforman los órganos, se seleccione y depure al personal que ha de manejarlos, y como, rigiendo íntegramente los preceptos legales vigentes, tal selección no sería posible, el Gobierno, opuesto siempre a la infracción de las leyes, pero también siempre dispuesto a utilizar en bien del país las facultades excepcionales con que Vuestra Majestad le honró, considera necesario que durante un breve plazo de tiempo se suspendan las garantías que hoy favorecen igual y aún más a los funcionarios de servicios deficientes o de escaso celo que a los de constante labor distinguidos en el cumplimiento de sus deberes". Consciente el ministro de las consecuencias de tales planteamientos, se justifica a continuación señalando: "Y, aunque no era preciso consignarlo, espontáneamente hace constar el Ministro que suscribe su sincero propósito de no hacer de las facultades extraordinarias que se le confieran otro uso que el que inspire su rectitud de conciencia y de intención ante la realidad de los defectos que compruebe". De acuerdo con la exposición de motivos, por el citado Real Decreto-Ley quedaba suspendida durante seis meses la inamovili-

\footnotetext{
${ }^{45}$ El Sol de 17 de diciembre de 1927.

${ }^{46}$ Ya con anterioridad, en sesión de la Asamblea celebrada con fecha 13 de ese mismo mes, el Ministro de Justicia y Clero, Señor Ponte Escartín, había planteado su intención de suspender la inamovilidad judicial, reservando a su persona la suspensión y separación de los funcionarios de la Administración de Justicia «Yo deseo conocer que la Asamblea piensa acerca de la conveniencia, de la necesidad, para que esa revolución en la Justicia se realice, se suspendan todas las garantías que hoy aseguran en sus cargos, en sus puestos, a los funcionarios de Justicia, seguros la Asamblea y el Gobierno, cuando se lo ofrezca, de que el uso que yo he de hacer de esta autoridad ha de ser siempre pensando en Dios para el porvenir y en mi Patria para el presente, seguros de que a nadie he de causar un perjuicio injustificado, de que he de procurar tan sólo el bien de la Justicia, limitándome a separar, cuando haya que separar, a suspender cuando haya que suspender a los funcionarios que, por cualquier circunstancia, no estén en condiciones de realizar las funciones que en la actualidad desempeñan», en Diario de Sesiones 19281929 , pp. 220 y 221.

${ }^{47}$ Arts. 1 y 2. Ver Salazar Alonso, op. cit., pp. 154-159, A. Agúndez, op. cit., p. 168.
} 
dad judicial. Durante ese plazo y previo acuerdo del Consejo de Ministros, el ministro de Justicia y Culto, cuando considerase que por achaques de edad o de salud o por otras circunstancias, la labor de los funcionarios judiciales, fiscales, del secretariado y auxiliares, no producía el rendimiento legítimo y razonablemente exigible en pro de la mejor administración de justicia, podría decretar la jubilación, excedencia forzosa o el traslado del funcionario. Dichos acuerdos no requerían expedientes de detallada sustanciación, ni otros informes que los que las circunstancias de cada caso permitan considerar necesarios. Contra tales acuerdos, se podía recurrir ante el Consejo de Ministros, el cual resolvía de plano; no procediendo recurso contencioso administrativo contra ninguna de ambas resoluciones ${ }^{48}$.

La injerencia del ministro en la administración de justicia no podía ser más grave y consecuentemente fue duramente criticada. Para Salazar Alonso se trataba de una verdadera "ofensa al sentido jurídico" y constituía un "atentado a todos los principios de nuestro derecho» ${ }^{49}$. Asimismo, a iniciativa de Ossorio y Gallardo, se convocó una reunión para estudiar el modo de protestar; pero ante la total desconfianza de la efectividad de la misma, con poco entusiasmo y un gran desaliento, se confió la cuestión al Sr. Cierva, Decano del Colegio de Abogados, lo que supuso que terminara por naufragar ${ }^{50}$. Duramente crítico con el Real Decreto-Ley fue Víctor Pradera, quien en una interpelación al Ministro en la Asamblea, y después de defender el principio de la inamovilidad judicial «La inamovilidad judicial no es un capricho de las leyes, no es un punto en el cual quepa discutir», así como las primeras medidas adoptadas por la Dictadura con respecto a la «función» judicial; arremete contra el devenir del régimen en este aspecto y de manera especial contra el Ministro de Gracia y Justicia ${ }^{51}$ y la suspensión de la inamovilidad por él llevada a cabo ${ }^{52}$. A dicha interpelación respondió el Ministro, quien después de destacar que se trataba de un disposición aprobada por el Gobierno en pleno y aceptada por la Asamblea, y defender la rectitud de su comportamiento ${ }^{53}$, concluye a modo de resumen diciendo: «inamovilidad para todos los funcionarios, para los judiciales especialmente, pero para defenderlos nada

\footnotetext{
${ }^{48}$ Arts. 9, 10 y 11.

${ }^{49}$ R. Salazar Alonso, op. cit., p. 162. En parecidos términos se pronuncia Saldaña, quien considera que el tenor del citado Decreto-Ley «se inscribe en las páginas negras de la Historia del absolutismo», en op. cit., p. 29.

${ }^{50}$ Ibidem, pp. 162 y 163.

${ }^{51}$ «... aquellos hombres que llegaban de los cuarteles para tomar las riendas del Poder, aquellos hombres que no estaban educados dentro de las prácticas del Derecho, sintieron el Derecho como no lo han sentido después hombres de la carrera judicial», en Diario de Sesiones de la Asamblea Nacional, Sesión de 22 de marzo de 1929, pp. 577 y 578.

52 «Vamos a hacer la revolución y para hacer la revolución en las leyes necesitaba el Sr. Ministro de Gracia y Justicia que eso que es tan delicado, la inamovilidad judicial, se le diera en prenda, y se le dio, y el señor Ministro de Gracia y Justicia empezó a hacer uso de la inamovilidad judicial», en Ibidem, p. 580. Ver. A. Agúndez, op. cit., p. 169.

${ }^{53}$ «Y cuando del uso de esas facultades resulta que ha sido precisamente para jubilar en todos los casos
} 
más, en cuanto ellos procedan bien y los Gobiernos procedan mal; más inamovilidad limitada para que los Gobiernos puedan defenderse de sus malos servicios o de sus servicios deficientes $\rangle^{54}$.

Las consecuencias de las nuevas medidas adoptadas no tardaron en aparecer. Dos días después de promulgado el citado Real Decreto-Ley, se procedió a las primeras jubilaciones en aplicación del mismo ${ }^{55}$.

La mayor parte de los periódicos del momento recogieron la noticia de la promulgación del nuevo Real Decreto-Ley, como era habitual, ateniéndose a los términos del mismo y sin comentario alguno al respecto. La excepción a lo anteriormente expresado, la encontramos en un pequeño comentario publicado en La Voz de 26 de diciembre, en el que se alude a esta falta de libertad «La disposición ya está publicada, y es lógico, con la lógica de toda dictadura, que sobre el fondo de ella no sea tolerado comentario que pudiera tratar de esterilizarla» o en La Época del 29 de Enero de 1929 , en la que se publica una información facilitada por el propio gobierno «En la Oficina de Información y Censura de Prensa han facilitado las siguientes copias de la carta dirigida por el Presidente de la Academia de Jurisprudencia al señor Presidente del Consejo y de la contestación de éste relativa a la inamovilidad judicial». En la primera de ellas, el Sr. Ossorio y Gallardo, en su calidad de Presidente de la Academia, trasladaba al Presidente del Consejo de Ministros, la preocupación de la misma por el contenido del Real Decreto aprobado ${ }^{56}$, deplorando el mismo. Dejando de un lado su análisis desde un punto de vista político, «más como se trata de hechos políticos, y en la política no puede mezclarse, nada en concreto ha de alegar», se pronuncia en su aspecto doctrinal «cumpliendo los artículos quinto, número tercero y 54 de sus Constituciones, que la mandan informar, dictaminar y consultar sobre las reformas legislativas... y mirando la anunciada reorganización del Poder judicial»,

de que habla el Sr. Pradera y que no he destituido ni he separado a un solo funcionario (lo cual no quiere decir que no haya de hacerlo en lo sucesivo, porque me reservo todas las facultades que ese Decreto atribuye al Gobierno)» en Ibidem, p. 581.

${ }^{54}$ Ibidem, p. 583.

${ }^{55}$ En palabras de Vicente Pradera en su interpelación a la Asamblea, tan solo fueron tres Magistrados del Tribunal Supremo y dos Magistrados de la Audiencia de Barcelona los que fueron «destituidos o jubilados». Palabras a la que respondió el Ministro, diferenciando entre jubilación y destitución, y destacando que «a pesar de estar autorizado para ello por la Asamblea y el Gobierno, no he destituido a nadie», en Ibidem, pp. 580, 581 y 582. Salazar Alonso, en op. cit., pp. 164 y 165, alude a que la rapidez con que se aplicó el Real Decreto Ley «hacía que las gentes relacionaran la medida con el fallo de un pleito que interesaba a la Compañía Trasatlántica». Ver también $\operatorname{La}$ Voz, 26 de diciembre de 1928. Uno de los magistrados jubilados por aplicación del citado Real Decreto-Ley, don Santiago del Valle, disconforme con la resolución adoptada agotó todas las vías a su alcance para luchar contra la misma. A pesar de su inquebrantable lucha, la medida adoptada no fue modificada, resultando rechazados todos los recursos interpuestos. Su restablecimiento se operaría, una vez caída la Dictadura, al ser designado Fiscal del Tribunal Supremo (extremos que se detallan con mayor minuciosidad en las páginas finales del presente artículo) en Salazar Alonso, op. cit., pp. 169-176. Ver también A. Agúndez, op. cit., p. 169.

${ }^{56}$ Refiriéndose a la inamovilidad judicial, «El Real Decreto de 22 de diciembre último ha dejado en 
hace una defensa de la inamovilidad de los jueces al considerarla el "cimiento de una justicia independiente y austera" y solicita del Consejo de Ministros: «Primero. Que haciendo uso el Gobierno de las facultades que se reservó en el artículo noveno del Real decreto de 22 de diciembre, acuerde poner término desde luego al plazo de seis meses fijado para tener en suspenso la inamovilidad judicial. Segundo. Que al regular nuevamente el Poder judicial, mantenga con firmeza el principio de la inamovilidad». En la respuesta por parte del Presidente del Consejo de Ministros, éste manifiesta no compartir su opinión «ni de un modo doctrinal puro, ni menos en cuanto pueda conectarse con un régimen excepcional, como es siempre la Dictadura», dejando claro sin ambages el intervencionismo del poder ejecutivo sobre el judicial «he de manifestarle que para mí lo esencial no es la inamovilidad del personal judicial, sino su eficiencia o capacidad moral, técnica y aun física, que al juicio de alguien hay que someter, y que al mío, nadie tan llamado a formularlo y hacerlo efectivo por sus resoluciones como el Gobierno, en el que deben aunarse todas las atribuciones y todas las responsabilidades...».

Los planteamientos contrarios a la autonomía del poder judicial esgrimidos en la respuesta de Primo de Rivera, son ratificados de nuevo en una entrevista realizada al mismo y publicada con fecha 2 de enero de 1929, en la que el Dictador vuelve a incidir en el control necesario del Gobierno sobre la actividad de los jueces «Presupuesto que si la justicia hubiera podido actuar debidamente la dictadura no hubiera sido precisa, mientras ésta gobierne es prudente tener a aquélla sometida a normas y vigilancia especiales, para que su incubación, deformada por la política, no la haga ser ni servil ni rebelde. La Justicia no es de ningún Gobierno, pero ha de ser siempre gubernamental y comprensiva con las circunstancias» ${ }^{57}$. Como se observará, las palabras del Presidente del Consejo de Ministros no dejan lugar a dudas.

La revolución de la justicia prometida por Ponte Escartín continua con toda su energía. Con fecha 6 de julio de 1929, La Sección $1^{\text {a }}$ de la Asamblea Nacional Consultiva presenta ante la misma un «Anteproyecto de Constitución de la Monarquía Española». En su título X dedicado al Poder Judicial, se vuelve a consagrar la independencia del mismo, pronunciamiento retórico al que estamos acostumbrados y que dista mucho de su aplicación práctica, al consignarse en el art. 47.4. de la misma, como competencia del Consejo del Reino, el proponer al Rey el nombramiento de presidente, presidentes de Sala, fiscal y magistrados del Tribunal Supremo. En definitiva, la cúpula del Poder Judicial $^{58}$. De acuerdo con el citado anteproyecto, e incluso con dos meses de anterioridad a su presentación ante la Asamblea Nacional, la citada Sección $1^{\mathrm{a}}$, aprobó una propuesta sobre «Organización del Poder judicial y contenido, límites y garantías de

suspenso el mecanismo legislativo que la garantizaba, poniendo en precario los destinos de todos los magistrados, jueces, fiscales y secretarios de España».

${ }^{57}$ El Imparcial, miércoles 2 de enero de 1929.

${ }^{58}$ Aspecto que suscita reservas en algunos de los juristas de la época, como es el caso de Alfonso Dranguet, quien sin ser excesivamente crítico con la redacción del proyecto constitucional, al hablar incluso 
la función que ejerce ${ }^{59}$, propuesta que no pasó de ser una mera iniciativa, pero que sin embargo viene a ratificar claramente la mentalidad que caracterizaba al gobierno con respecto del Poder Judicial. El título primero vuelve a insistir en utilizar las mismas palabras vacías de contenido «De la independencia del Poder Judicial», independencia que aparece recogida en su art. 1 "El Poder Judicial se ejerce en nombre del Rey, por los Tribunales y Juzgados, que gozan de plena independencia respecto de los demás Poderes", atribuyéndose al Tribunal Supremo la facultad de nombrar, ascender y separar a los Magistrados, Fiscales y Jueces ${ }^{60}$, con la excepción de los propios integrantes del mismo, cuyo nombramiento y designación se confiere a Consejo del Reino ${ }^{61}$, órgano de claro carácter político. Se crea El Directorio judicial que, como órgano del Tribunal Supremo y junto con el Presidente de éste último, ejercerá la función gubernativo-judicial ${ }^{62}$. El nuevo órgano estaría integrado por los Presidentes de las Salas del Tribunal Supremo, El Fiscal y los Magistrados Inspectores de la Administración de Justicia, cuyos miembros serán inamovibles ${ }^{63}$, y bajo la presidencia del Presidente del Tribunal Supremo, le competía el nombramiento, ascenso y separación de todos los Jueces, Magistrados, Fiscales, auxiliares y subalternos de la Administración de Justicia ${ }^{64}$. El Consejo judicial continúa existiendo con facultades meramente consultivas, y con una composición no estrictamente de origen judicial ${ }^{65}$. La inamo-

de «sinceridad de los redactores del articulado», sin embargo no se muestra partidario del mismo "nos lleva a mostrar el deseo de que se suprima tal forma de nombramientos». Junto al punto tratado, el citador autor, se muestra, asimismo, disconforme «con la redacción presentada en otros aspectos, como son: la designación del Ministerio Fiscal como órgano de comunicación entre el Poder ejecutivo y el judicial (art. 101), la resolución de los recursos de competencias entre los representantes del órgano ejecutivo y los del judicial (art. 47.1.), la exclusión de los Tribunales para decidir sobre la constitucionalidad de las leyes (art. 93), y su atribución al Consejo del Reino, así como, encomendar a este último, la facultad de juzgar a los ministros de la Corona, consejeros del Reino, presidente, fiscal, Pleno, Salas, Presidentes de Sala y magistrados del Supremo» (art. 47.3), función estrictamente de carácter judicial. Por el contrario reivindica la necesidad de que se consagre en la Constitución el requisito de que el presidente del Tribunal Supremo tenga asiento en la Cámara popular para intervenir directamente en la discusión de las leyes que afecten al Poder Judicial, sus presupuestos y contestar a cualquier interpelación que se formule y que roce estas cuestiones, en Responsabilidad e independencia del Poder Judicial, Madrid, 1930, pp. 257-269.

${ }^{59}$ Diario de Sesiones de la Asamblea Nacional, Apéndice $5^{\circ}$ al no 48 .

${ }^{60}$ Art. 5.

${ }^{61}$ Art. 6.

${ }^{62}$ Art. 15.

${ }^{63}$ Art. 22.

${ }^{64}$ Arts. 19 y 20.

${ }^{65}$ Art. 27 y 30 . Por lo que se refiere a su composición, junto con los funcionarios judiciales y fiscales, se incorporan dos individuos de la Comisión general de Codificación, El Decano del Colegio de Abogados de Madrid, El Decano de la Facultad de Derecho de la Universidad Central y dos letrados, propuestos por el Consejo del Reino. Aspecto éste último que va a ser criticado por Alfonso Dranguet, quien considera «huelgan los seis vocales, decanos del Colegio de Abogados y de la Facultad de Derecho, los dos miembros de la Comisión general de Codificación y los dos letrados designados por el Consejo del Reino». Asimismo, el mencionado autor, defensor de la existencia del Consejo Judicial, de acuerdo 
vilidad judicial, que se encontraba suspendida, como se señala anteriormente, vuelve a consagrarse de acuerdo con el proyecto constitucional ${ }^{66}$.

Las nuevas propuestas gubernamentales suscitaron amplios comentarios en la prensa, tanto con respecto al nuevo proyecto constitucional, en general ${ }^{67}$, como en lo que se refiere en particular al proyecto de Ley sobre Organización judicial. Se critica abiertamente las competencias atribuidas al Consejo del Reino en lo referente a los nombramientos de los miembros del Tribunal Supremo "Lo peor del proyecto de ley sobre contenido, límites y garantías de la función judicial, y lo que en consecuencia pone en mayor peligro la independencia del Poder que desempeñará esta función, es el traspaso al Consejo del Reino, órgano esencialmente político, del nombramiento de las personas que han de constituir el Tribunal Supremo, y la mayor de las atribuciones que el Poder Judicial habría de tener y deseamos que tenga" ${ }^{98}$, considerando que éste se constituye en la cabeza del Poder Judicial y el Tribunal Supremo en un Tribunal inferior. Se plantea, asimismo, la función del recién creado Directorio Judicial, en este sentido ${ }^{69}$, concluyendo que ha resultado vana la esperanza puesta en las nuevas reformas "y después de tanto esperar, queda deshecho lo más grande y más renovador de la espera, loca espera según vemos"70.

La necesidad de reformas en la Administración de Justicia no solo es sentida por los órganos de gobierno, sino que aun con un sesgo muy diferente, en general, son promovidas por los ejercientes del foro. Este es el caso de García González, quien en 1928 publica unas «Bases para la Organización completa del Poder Judicial y Radical organización de la Justicia Municipal», en las que aparte de proponer algunos cambios de nomenclatura para determinados órganos, como es el uso del término de Justicia

con la normativa vigente, no comprende su creación en la nueva, al considerarlo como «una cuña que se introduce en el cuerpo judicial», que no tendrá vida o su labor será contradictoria, en determinados supuestos, con la del propio Directorio judicial, en op. cit., pp. 273 y 274.

${ }^{66}$ Arts. 60 y 61.

${ }^{67}$ Ver, entre otros, El Sol, 24 junio de 1929, La Voz y El Heraldo de Madrid, ambos de 31 de julio de 1929, La Epoca, 5 de agosto de 1929, La Libertad, 6 de agosto de 1929, El Heraldo de Madrid y La Voz, ambos de 7 de agosto de 1929. Ante los comentarios suscitados por las nuevas reformas, el Dictador se sintió en la obligación de salir al paso de los mismos, y concretamente en alusión a uno de ellos publicado en el Diario $A B C$, por José Cuartero, El Presidente del Consejo, considero conveniente responder al mismo. Respuesta que fue publicada a continuación del artículo que la había originado «La Oficina de Censura nos ruega, en nombre del señor presidente del Consejo, publiquemos a continuación del artículo del Sr. Cuartero la siguiente: Nota del señor presidente del Consejo. «El artículo anterior requeriría comentario extenso y documentado para contrarrestar en el ánimo del lector la impresión que con él se trata de producir... Primera. El Proyecto o ponencia constitucional elaborado por la Asamblea Nacional a unos pareció malo; a otros, peor, y a muchos, bueno; sino que éstos no han merecido atención de la Prensa hostil o prevenida, que es la mayor parte», en El Sol, 31 de diciembre de 1929.

${ }^{68}$ El Sol, 24 de junio de 1929.

${ }^{69}$ «¿Por qué el directorio judicial estatuido por el proyecto que comentamos no habrá de tener la atribución de nombrar a todos los magistrados del Supremo Tribunal?», en Ibídem.

${ }^{70}$ Ibidem. 
Mayor ${ }^{71}$ para designar al Presidente del Tribunal Supremo, o el de Corte de Casación, para el citado tribunal, reivindica una Administración de Justicia verdaderamente independiente, sin dependencia alguna del arbitrio o interpretación ministerial. Para lo cual, plantea la creación del «Justiciazgo», como máxima representación del poder judicial $^{72}$, y defiende, asimismo, la inamovilidad de los jueces ${ }^{73}$.

De características diferentes al anterior, en cuanto defiende una dependencia del gobierno de la Justicia del Ministerio de su nombre, es presentado un nuevo Anteproyecto en el año 1929, cuyo autor es Ramón del Valle ${ }^{74}$.

De todos estos proyectos de carácter privado, el que más repercusión tuvo, sin duda alguna, sería el elaborado por Ossorio Gallardo, persona manifiestamente crítica con el gobierno y non grata y perseguida por el mismo, publicado en 1929, bajo el título «Bases para la reorganización Judicial» ${ }^{75}$, en cuya introducción declaraba como directriz fundamental que había guiado su pensamiento «que la Justicia ha de ser un verdadero Poder ${ }^{76}$. De acuerdo con el mismo, sus bases constituyen una concepción de la organización judicial claramente independiente de los otros poderes y concretamente del Ejecutivo. En su Base $1^{\mathrm{a}}$ abogaba por una Administración de Justicia constituida como Poder del Estado, integrada por el personal de la Magistratura, la Judicatura, el Secretariado judicial y subalternos, cuyo régimen interno competía al Consejo judicial, y su personificación, como tal Poder, al Presidente del Tribunal Supremo, quien tendría asiento en las Cámaras, en las que respondería a las preguntas, interpelaciones y proposiciones que le pudieran dirigir los Senadores y Diputados ${ }^{77}$. En su Base $2^{\text {a }}$, quedaba

\footnotetext{
${ }^{71}$ Nombrado por las Cortes a propuesta del Gobierno, de entre los magistrados del Supremo, p. 55.

${ }^{72}$ «El Justiciazgo tiene un Consejo judicial, formado a base de la Junta de Gobierno, o Capítulo del Tribunal Supremo, que a la vez que Junta de Gobierno del propio Tribunal Supremo, es la comisión permanente del Consejo judicial, y despacha todos los asuntos de puro trámite, como propuestas, ascensos y ceses reglamentarios y para lo resolutorio se completa agregándole cada tercer año la tercera parte de los magistrados del Supremo, por índice de letras, y los Inspectores de la Administración de Justicia; o bien una cuarta parte, pero excluyendo elementos extraños al Poder Judicial, como son los Decanos de Abogados, de la Facultad de Derecho, ni de la Academia de Jurisprudencia ni de la Comisión Codificadora...», p. 51 .

${ }^{73}$ «... esta debe entenderse de distinta manera a como se la entiende hoy. La inamovilidad debe consistir en no poder ser removido de su carrera sino por las causas legalmente establecidas, por las autoridades o tribunales que reconocen la ley orgánica y en no ser trasladado sino por sus superiores naturales», p. 77. ${ }^{74}$ J. Hijas Palacios, "Pasado, presente y futuro de la Ley Orgánica del Poder Judicial", Revista de Derecho Judicial, Año XI, Julio-Diciembre 1970, p. 400.

${ }^{75}$ Publicado en Madrid, aunque el autor en su introducción advertía que las ideas plasmadas en las citadas bases ya habían sido expuestas en distintas conferencias pronunciadas en la Real Academia de Jurisprudencia y publicadas bajo el título La Justicia Poder, Madrid, 1927,

${ }^{76}$ Op. cit., p. 12. Ver también J. Hijas Palacios, op. cit., p. 401.

${ }^{77}$ No incluía al Ministerio Fiscal como elemento integrante del Poder Judicial, al establecer un régimen distinto para el mismo. En la Base 31 a dedicada a esta figura quedaba regulada de la siguiente forma: «El Ministerio Fiscal seguirá ajustado, en líneas generales, al Estatuto de 21 de junio de 1926, con estas modificaciones: $1^{\text {a }}$. Como representante que es del Gobierno en sus relaciones con el Poder Judicial, dependerá de la Presidencia del Consejo de Ministros, a la cual corresponderá el régimen de su personal
} 
consagrado el principio de inamovilidad judicial, remitiendo a la Ley Orgánica vigente las causas de destitución ${ }^{78}$. Incluía en su Base $3^{\text {a }}$, la supresión del Ministerio de Justicia y Cultos, y distribuía sus funciones entre el Presidente del Tribunal Supremo, el Departamento de Negocios extranjeros (las relaciones con la Iglesia), una Dirección general para los establecimientos penales y otra Dirección para los restantes servicios del Ministerio; pasando a depender del Consejo Judicial el personal judicial ${ }^{79}$. En el capítulo III (Bases $8^{\mathrm{a}}$ a $16^{\mathrm{a}}$ ), bajo el epígrafe «De los ingresos, ascensos, servicios y jubilaciones del personal judicial», se establecía que los ascensos en la judicatura eran conferidos al Consejo Judicial y por rigurosa antigüedad de servicios en la Carrera. La Base 17 , dentro del Capítulo dedicado al Tribunal Supremo, constituía a éste como el organismo superior del Poder Judicial, pero sin formar parte de la carrera judicial ${ }^{80}$. Al Consejo Judicial, órgano de extrema importancia en las presentes bases, se dedicaba el Capítulo $\mathrm{V}$ en su integridad. Asumía la jurisdicción gubernativa de todo el personal judicial (nom-

en el orden administrativo». Las ideas expuestas por Ossorio Gallardo en la base citada son asumidas por muchos otros autores; como muestra, ver las notas de S. Sentís Melendo, en la edición realizada en Buenos Aires, 1961, de la obra de Ossorio Gallardo, bajo el título La Justicia, vol. II, pp. 17-18 y 7880, o Alfonso Dranguet, quien se expresa totalmente a favor de la presencia del Presidente del Supremo en la Cámara y añade: «El Sr. Azcárate, ....y agregaba: Mientras no haya en el Parlamento, al lado del banco azul, un banco rojo, en el que se sienten el presidente y fiscal del Tribunal Supremo, el Poder Judicial no será independiente», en op. cit., p. 260.

${ }^{78}$ «Los funcionarios judiciales son inamovibles. No podrán ser destituidos sino por el Tribunal Supremo en pleno, asistiendo, por lo menos, dos terceras partes de sus miembros y votando la destitución dos terceras partes de los presentes. Para la destitución se necesita expediente previo en que sea oído el interesado, propuesta del Consejo Judicial y dictamen favorable del Ministerio Fiscal».

${ }^{79}$ Punto controvertido éste de la desaparición del Ministerio de Justicia y Cultos. Hay autores que lo defienden, como requisito indispensable para poder hablar de una autonomía plena del Poder Judicial, como es el caso, entre otros, de Bergamín, extremo recogido por Alfonso Dranguet, en op. cit., p. 279. Ver también J. Sánchez-Rivera, en conferencia pronunciada en la Academia de Jurisprudencia, El Heraldo de Madrid, 2 de abril de 1929, así como el Editorial en El Sol, 5 de mayo de 1929; para otros, sin embargo, se trata de un error, «pretender suprimir el Ministerio de Justicia y crear otro en la presidencia del Supremo es vulnerar los más elementales principios del Derecho Constitucional, puesto que es arrancar del Gobierno funciones peculiares del Poder Ejecutivo», en A. García González, El Poder Judicial, Madrid, 1932, p. 139.

${ }^{80}$ «Su misión en lo político, es impedir la extralimitación de los poderes del Estado; en lo judicial, resolver definitivamente, por las vías que señalen las leyes, los asuntos civiles, penales, sociales y contencioso-administrativos; y en lo gubernativo, desempeñar las funciones que hoy están atribuidas al Ministerio de Justicia, excepto las relaciones con la Iglesia». Para Alfonso Dranguet, el autor de las bases, incurre en el error de estimar que el Supremo no deba formar parte de la carrera judicial, aunque también considera que, como ha de asignarle como función especial la de juzgar, poco importa que lo sitúe donde crea, en op. cit., p. 263. Tampoco se manifiesta acorde con las citadas Bases, Sentis Melendo, quien en notas a las mismas, señala que eliminándose la afirmación de que el Tribunal Supremo no forma parte de la Carrera judicial, las relaciones entre el mismo y el Consejo Judicial resultarían más sencillas, y continua diciendo: «Me parece que no puede ser el Tribunal Supremo ajeno a la Carrera, y ser el Consejo tan de la Carrera; que sería más natural considerar al Tribunal Supremo como el organismo más alto de los que integran la Carrera; y, por el contrario, el Consejo debería formarse con elementos no sólo de la Carrera sino también ajenos a ella», en op. cit., p. 65. 
bramientos, ascensos, destinos, traslados, excedencias, licencias, abonos de haberes, dietas y gastos, premios, etc). También le correspondía la Inspección de Tribunales y la jurisdicción disciplinaria. Estaría presidido por el Presidente del Tribunal Supremo y compuesto, como vocales, por un funcionario de cada una de las categorías de la Judicatura, la Magistratura y el Tribunal Supremo ${ }^{81}$. Ya en el Capítulo VII, se regulaba la responsabilidad de los funcionarios judiciales ${ }^{82}$.

Como se observará, las anteriores bases constituían una verdadera transformación en la administración de justicia, sentando los cimientos de un verdadero Poder Judicial independiente, a diferencia, tanto de las medidas que había venido adoptando el Gobierno, como de los principios recogidos en el Anteproyecto de Ley sobre Organización del Poder Judicial propuesto a la Asamblea Nacional por la Sección 1 a de la misma con fecha 6 de mayo, anteriormente aludido.

La importancia de las citadas Bases se puede deducir del impacto que la publicación de la obra tuvo en los periódicos del momento. Son muchos los diarios que se hacen eco de la noticia y las entrevistas que se hacen a su autor. En los mismos se ensalza tanto la figura de su artífice, como crítico contra las actuaciones del régimen imperante «Figura actual, por muchas razones predominante. Cuando menos, por haberse librado de la endémica mudez sin trigémino que venimos padeciendo durante un quinquenio» ${ }^{83}$, como su calidad de jurista $»$ Este de las Bases queda convertido, por su propia virtualidad, en documental prueba de su capacitación, preparación y suficiencia, determinantes de un general y favorable veredicto. Los problemas judiciales encuentran en su cultura y en sus atisbos insospechados soluciones inspiradas en un elevadísimo concepto de la justicia y en una clara percepción de su trascendencia y de cómo se la debe servir» ${ }^{84}$. Por lo que se refiere a la propia obra, es considerada como la base sobre la que debería girar la nueva reorganización de la Justicia ${ }^{85}$.

Tanto las reformas propuestas por el Gobierno, como las iniciativas de carácter privado, no pasaron de tales. La Dictadura se desmoronaba y Primo de Rivera intentaba, sin lograrlo, establecer las bases que sirvieran para dar continuidad a un régimen presidido por una persona de su absoluta confianza y que mantuviera su obra "Juzga

\footnotetext{
${ }^{81}$ Ver las observaciones recogidas de Sentís Melendo en nota anterior.

${ }^{82}$ J. Sánchez-Rivera, quien suscribe las Bases de Ossorio y Gallardo, sin embargo en este punto difiere de lo contemplado por su autor, en el siguiente sentido: "que la responsabilidad civil y criminal de jueces y magistrados sea exigible ante un Jurado popular, ya que conceder a los propios jueces el derecho a juzgarse a sí mismos por delitos cometidos en el ejercicio de sus cargos es impedir toda responsabilidad judicial efectiva", en El Heraldo de Madrid, 2 de abril de 1929.

${ }^{83}$ La Libertad, 31 de mayo de 1929.

${ }^{84}$ Ibidem. Ver también El Sol, 2 de marzo y 19 de mayo de 1929.

${ }^{85}$ El Sol, 2 de marzo y 5 de mayo y 18 de julio de 1929, El Heraldo de Madrid, 2 de abril de 1929, al recoger la conferencia pronunciada por el académico y profesor don Juan Sánchez Rivera, señala lo siguiente: «Cree pueden ser excelente ponencia para la reorganización judicial las bases recientemente publicadas por el Sr. Ossorio y Gallardo»
} 
Primo de Rivera que no puede abandonar la Presidencia sin dar una nueva Constitución y organizar un partido" $"$.

La Dictadura desapareció el 30 de enero de 1930, sin lograr los propósitos del Dictador: dejar establecidas las bases que hubieran podido dar continuidad a su régimen. Al gobierno caído le sucederían los nuevos, presididos por El General Berenguer y Almirante Aznar-Cabañas ${ }^{87}$, sin que en ninguno de ellos se adoptaran medidas que implicaran un cambio sustancial en el ámbito de la administración de justicia ${ }^{88}$. Recién estrenada la II República, se promulga un Decreto con fecha 19 de mayo, por el cual queda disuelto El Consejo Judicial, al considerar, según se establece en el mismo, el deber del Gobierno en «hacer desaparecer los organismos que fueron creados durante los pasados Gobiernos dictatoriales» y alegando como razones de su decisión, "que no cuenta con la aprobación ni con el apoyo de la mayoría de la Magistratura, que, por el contrario, le condena y pide su inmediata disolución".

\section{Espíritu que caracterizó la actuación práctica del Ejecutivo frente a la magistratura}

Expuestas las líneas que marcan el desarrollo normativo en esta etapa, no cabe la menor duda que nos encontramos ante un periodo de claro retroceso en el logro de un Poder Judicial independiente del Ejecutivo. El conjunto de modificaciones aprobadas por el Ministerio de Gracia y Justicia, junto con aquellas propuestas por su titular y que quedaron como simples proyectos sin plasmación legislativa como consecuencia de la caída del régimen, no hacen sino poner de manifiesto una persecución sin dilaciones contra un poder de los jueces independiente. Los buenos propósitos con que se había estrenado el régimen dictatorial y que comenzaron a declinar en la primera etapa de la dictadura ${ }^{89}$, entran en un total olvido acentuado y progresivo. Es importante resaltar que los golpes más decisivos contra la independencia de los jueces no se operan mientras el encargado de los asuntos de la justicia es un militar,

\footnotetext{
${ }^{86}$ El Sol, 31 Diciembre 1929. El editorial de El Debate, no compartía este criterio del Dictador, y considerada que la única razón que podría tener el Marqués de Estella para constituir un partido «suyo», sería la de que por medio del mismo se perpetuase en el Poder la obra de la Dictadura y el hacer respetable su nombre una vez que dimitiera, y agregaba "Pero el sucesor no puede ser más que un hombre de la absoluta confianza de Primo de Rivera, para que sea un continuador de su obra", recogido en El Sol, 31 Diciembre 1929.

${ }^{87}$ Gobierno de Berenguer (30 enero 1930-18 febrero 1931). Gobierno de Aznar-Cabañas (18 febreroabril 1931).

${ }^{88}$ Por Real Decreto de 24 fe febrero de 1930 del nuevo Ministro de Justicia y Culto, José Estrada y Estrada, vuelve a verse afectada la Justicia municipal, al ordenar el cese de todos los Jueces y Fiscales municipales y suplentes de los mismos, de nuevo alegando la necesidad de «garantir la moralidad, aptitud e independencia de los llamados a intervenir en los juzgados municipales», en J. Damián Moreno, Los Jueces de Paz, Madrid, 1987, pp. 143 y 144.

${ }^{89}$ Ver mi artículo "La Independencia del Poder Judicial...".
} 
sino que estos se producen, constituido ya el Ministerio de Gracia y Justicia, presidido por una figura perteneciente a la carrera judicial, como era Ponte Escartín, quien intervino denodadamente para fortalecer el poder ejecutivo en detrimento de la carrera de la que había formado parte ${ }^{90}$.

A diferencia del primer periodo (1923-1926), en que se adoptaron medidas claramente revolucionarias en lo referente a la consecución de una verdadera independencia del Poder Judicial, como fue la creación de La Junta Organizadora del Poder Judicial, respetadas en mayor o menor medida en la práctica, como tuvimos ocasión de constatar ${ }^{91}$; en esta segunda etapa, fortalecida normativamente la intervención directa del Poder Ejecutivo en los asuntos judiciales, con medidas como la creación del Consejo Judicial o el atentado contra la inamovilidad de los jueces, entre otras, no se daba lugar a posibles intervenciones indirectas y solapadas del Gobierno buscando el sometimiento de los jueces, ya que éste había sido delineado por la propia Ley. Esta es la razón de que los documentos de aplicación del derecho correspondientes a este periodo no denoten intromisiones irregulares del Ejecutivo en los ámbitos judiciales. No resultaba necesario recurrir a procedimientos irregulares, cuando la legalidad consagraba dicha preeminencia del Ministro en los ámbitos más decisivos de la organización judicial.

Aunque amparado en la legalidad creada a su antojo y propicia a sus intereses, el Ministro, Sr. Ponte Escartín, no dejó de manifestar su talante déspota en sus actuaciones. Extremos que hemos podido observar tanto del análisis directo de los documentos recogidos en distintos archivos, como de informaciones periodísticas o noticias recogidas por los autores de la época. Todos ellos referentes a casos muy singulares, pero que del tratamiento de su conjunto, permiten hacernos una idea de la actitud demostrada por el Ministro siempre que pudiera sentirse contrariado.

Como hemos podido observar anteriormente, de acuerdo con la legalidad vigente, al Ministro de Gracia y Justicia le competía la designación de los miembros del Consejo Judicial, ateniéndose a la terna propuesta por el propio Consejo. Se trataba, por tanto, de una designación arbitraria dentro de los tres indicados. Designación que, como es lógico, levantaba recelos entre aquellos que repetidamente sugeridos por el Consejo, no lograban verse ungidos por el dedo del ministro ${ }^{92}$.

\footnotetext{
${ }^{90}$ Son muy significativas las palabras de Tusell a este respecto, quien nos dice: «De esta manera se contradecían ya claramente los propósitos reiteradamente proclamados de desvincular de la política la administración de la justicia», en op. cit., p. 182.

${ }^{91}$ Ver mi artículo "La Independencia del Poder Judicial...".

${ }^{92}$ Extremo que queda constatado en carta dirigida por el Presidente de la Audiencia de Badajoz, Don Angel Ruiz de Obregón, al Presidente del Consejo, Don Francisco García Goyena, en la que al no haber sido designado para la plaza vacante de la Secretaría del Consejo Judicial, agradece a este último y al resto de los Consejeros, el haber sido incluido por dos veces en la terna, pero manifestando su inquietud al no haber sido elegido por el Ministro «Me desorienta y confunde el hecho de que ambas veces hayan sido preferidos funcionarios de inferior categoría en un caso y de menos antigüedad en el otro, lo que parece indicar que pesa sobre mi alguna tacha (que desconozco y ni siquiera puedo sospechar) y que
} 
La actitud despótica del ministro, queda reflejada, asimismo, según destaca Salazar Alonso, en el caso relatado por el mismo, referente al traslado forzoso impuesto por el titular de Justicia al Juzgado de Hellín, con fecha 26 de junio de 1928, al hasta entonces Juez de Priego, Don Antonio Domínguez ${ }^{93}$. Las formas ${ }^{94}$ y la actitud demostradas por el Sr. Ponte ${ }^{95}$, así como las razones en que se sustentó esta necesidad de traslado ${ }^{96}$, no dejan lugar a dudas, de la consideración de la Justicia que caracterizó los planteamientos del citado ministro.

Otro caso singular se produce como consecuencia de la aplicación de Decreto de 22 de enero de 1929, que suspendía temporalmente la inamovilidad de los jueces. Uno de los magistrados jubilados con carácter inmediato por la citada medida, Don Santiago del Valle, perteneciente al Tribunal Supremo, no conforme con la misma, al considerarla un atropello injustificado, dirigió un escrito al Consejo de Ministros, «La adopción del acuerdo, que en este caso, y por lo que al que suscribe se refiere, tiene todas las apariencias y caracteres de una corrección disciplinaria, correlativo con la máxima falta» ${ }^{97}$, en el que solicitaba información acerca de los cargos resultantes y expediente instruido en el que motivara el acuerdo de jubilación. La respuesta al mismo declaraba no haber lugar a lo solicitado, sin perjuicio de que pudiera utilizar el recurso previsto en el art. 11 del Real Decreto formulando «cuantas alegaciones estime pertinentes». Alegaciones imposibles de efectuar cuando eran desconocidas

esa es la causa de mi preterición, tanto más cuanto hace más de un año el Ministro en persona me ofreció llevarme a Madrid en la primera ocasión favorable". Dicha carta es respondida por el Sr. García Goyena, donde resalta la inexistencia de tacha alguna en el aspirante que justifique su preterición, sino que por el contrario "todos reconocen y ha reconocido el Consejo por dos veces las excelentes cualidades que le adornar como funcionario competente, integérrimo, trabajador y de intachable conducta», y atribuye la competencia exclusiva del Ministro para la designación «V. comprenderá que de los tres propuestos, solo uno podía ser nombrado y en este trámite ya el Consejo no podía ni debía intervenir» Archivo General de la Administración, Fondos 7.13.3. Caja 27.626.

${ }^{93}$ Op. cit., pp. 195-199.

94 “Hallábame en mi despacho del Juzgado de Priego (Córdoba), cuando suena el teléfono, y, aplicado al auricular, me sorprende la siguiente noticia: «El ministro ordena que salga usted para Madrid por asuntos muy graves..», en op. cit., p. 195.

95 « ¿Cuál no sería mi sorpresa, cuando en la entrevista empieza por decirme que al haberme llamado había tenido conmigo una deferencia que no acostumbraba a tener con nadie (era la primera vez que nos veíamos); y que la llamada era, sencillamente, para comunicarme que tenía que salir de Priego y que eligiese, por tanto, algún Juzgado; lo que me abstuve de hacer, ya que todos los que se me ofrecían estaban en Galicia y ello me suponía unos gastos de traslado muy grandes», en op. cit., p. 196.

${ }^{96}$ «Tenía que salir de Priego porque me había resistido a procesar y, consiguientemente, a encarcelar a un señor que se le acusaba de un delito que estaba comprobado que no existía; pero, a pesar de esto, como dicho señor era pariente de un político del antiguo régimen y llevaba su mismo ilustre apellido, y como lo que se quería perseguir no era el delito, sino a este apellido...". "He dicho que mi sorpresa fue enorme, porque precisamente el sumario en cuestión hacía unos días que había llegado al Juzgado para su archivo, después de haber sido reproducida la petición del procesamiento ante la Audiencia por el mismo fiscal y haber sido también denegada", en op. cit., pp. 196 y 197.

${ }^{97}$ R. Salazar Alonso, op. cit., pp. 168 y 169. 
por el afectado, haciéndolo así constar en un nuevo escrito dirigido de nuevo al Consejo de Ministros ${ }^{98}$. El 15 de marzo el Boletín Oficial del Ministerio de Justicia y Culto publicaba una Real Orden disponiendo el archivo de la instancia ${ }^{99}$. No conforme con la resolución, el señor del Valle acudió a la Sala de lo Contencioso-administrativo, en un intento de apurar la vía legal contra una medida que consideraba injusta, aunque con un gran convencimiento de la inutilidad de su decisión «Cierto, también, que la propia jurisdicción contenciosa, efecto de las mutilaciones que viene sufriendo por parte del Poder ejecutivo, y de las facultades omnímodas que éste se arroga en cuanto a la ejecución de sus sentencias, da, asimismo, la sensación, hoy día, de un valor casi nominal» ${ }^{100}$. La Sala rechazó el recurso e igual suerte corrió el de súplica posterior. La irregularidad de la medida adoptada por el ministerio de Ponte Escartín quedó constatada con el nombramiento del citado Don Santiago del Valle, como Fiscal del Tribunal Supremo, días después de caído el gobierno de Primo de Rivera ${ }^{101}$.

Notoria y resaltada por la prensa, fue la sanción ${ }^{102}$ impuesta en los últimos meses del régimen al magistrado del Tribunal Supremo, Don Mariano Avellón y Quemada, con motivo del prólogo ${ }^{103}$ redactado por el mismo al libro del juez Don Alfonso R. Dranguet ${ }^{104}$. La difusión de dicha sanción contrarió al ministro, quien ordenó abrir un expediente, para averiguar el origen de la filtración, al considerarla irregular ${ }^{105}$.

Sanción que no dejó de tener consecuencias negativas para la persona del ministro Ponte, aun incluso después de cesar en el ministerio ${ }^{106}$. Como consecuencia del fallecimiento del Sr. Avellón y Quemada, acaecido el 5 de octubre de 1930, los periódicos retomaron el tema del castigo de que había sido objeto. Ante las nuevas noticias difundidas, el Sr. Ponte Escartín, no permaneció impasible y rápidamente solicitó la publicación de ciertas aclaraciones sobre las mismas, contribuyendo aún más a dejar en entredicho su actuación. El ex ministro indicaba que su actuación se había limitado, una vez conocida la publicación del citado prólogo, a comunicarlo «cumpliendo mi

\footnotetext{
${ }^{98}$ «... desconociendo los cargos que se me hacen, no es posible, en buena lógica, que yo formule los descargos correspondientes, ni alegación alguna que tienda a desvirtuarlos y a demostrar la improcedencia en derecho de la resolución que conmigo, y por motivos, si existen, que sigo desconociendo, se adoptó», en R. Salazar Alonso, op. cit., p. 172.

${ }^{99}$ Ibidem, p. 173.

${ }^{100}$ Ibidem, p. 174.

${ }^{101}$ Real Decreto $\mathrm{n}^{\circ} 332$, de 6 de febrero de 1930.

${ }^{102}$ En el expediente instruido contra el citado Magistrado se acordó imponerle al mismo la corrección de reprensión y suspensión de sueldo durante dos meses. La Época, 20 de noviembre de 1929.

${ }^{103}$ Prólogo que no contiene elemento ofensivo al poder establecido. En términos de Salazar Alonso «es un modelo de elegancia y sobriedad... Nadie señalará con justicia ni una sola palabra vituperable», en op. cit., p. 257.

${ }^{104}$ Responsabilidad e independencia del Poder Judicial, Madrid, 1930.

${ }^{105}$ Salazar Alonso, op. cit., pp. 257 y 258.

${ }^{106}$ Días más tarde de cesar como Ministro de Gracia y Justicia y a solicitud del mismo, se acordó su separación de la Carrera judicial y ser dado de baja en el Escalafón de la misma. Real Decreto $n^{0} 583$, de 24 de Febrero de 1930.
} 
deber» al Tribunal Supremo, a los efectos que fueran procedentes, no interviniendo en la posterior sanción impuesta por el citado Tribunal o su Sala de Gobierno. Aclaraciones que no hicieron más que empeorar su situación. Las mismas fueron respondidas con una cierta ironía, «icon azúcar está peor, D. Galo!» resaltando que no era su deber comunicar nada al Tribunal Supremo y provocando una serie de comentarios que merece la pena reproducir para conocer la imagen que del ministro se tenía: «No cabe mayor falta de sinceridad; pero tal notorio como esta falta es el hecho de que un miembro del Poder ejecutivo intervenía la función del Tribunal Supremo, no en funciones de alta inspección, sino produciendo la denuncia de un artículo publicado en una revista por el digno magistrado señor Avellón. Yo no volví a intervenir — dice—; ¿pero para qué tenía que hacerlo después de haberlo hecho? Basta que interviniera una vez para que deba ser censurada su conducta. Esta es la justicia que mandaba hacer D. Galo Ponte desde su poltrona ministerial» ${ }^{107}$.

La corrección disciplinaria acordada contra el Sr. Avellón traspasó los límites de los comentarios periodísticos para buscar en los tribunales el resarcimiento de la acción ejecutada por Ponte Escartín, al considerarla como el inicio del agravamiento del padecimiento experimentado por el Sr. Avellón en su estado de salud, que desembocó con el fallecimiento del mismo ${ }^{108}$. En efecto, con fecha 4 noviembre de 1930, Don Alejandro Durán Cantos, presentó denuncia contra D. Galo Ponte Escartín, fundada en los motivos anteriormente mencionados y haciendo una durísima exposición del carácter despótico de sus comportamientos ${ }^{109}$. En Auto dictado por el Tribunal Supremo constituido en Sala de Justicia con fecha 29 de ese mismo mes y año, se declaraba no haber lugar a admitir la denuncia, absteniéndose de todo procedimiento sobre la misma, y se ordenaba se pasasen dichas diligencias al Ministerio Fiscal, a los efectos que procedieran «en orden a las responsabilidades en que haya podido incurrir el denunciante» ${ }^{110}$.

\footnotetext{
${ }^{107}$ El Liberal, 11 de octubre de 1930. Ver también $A B C, 9$ de octubre de 1930.

108 «... que desde la fecha en que fue sometido a expediente el Sr. Avellón y Quemada se inició y sucesivamente fue intensificándose en él un estado neurósico agudo por consecuencia de las dolorosas impresiones sufridas... que el estado neurósico agudo referido y engendrado del modo expuesto, provocó el racional y clínico estado de agravación en sus crónicas afecciones renal y bronquial, que en un plazo de diez meses aceleró su muerte, en A.T.S., 021-9000039950003236.

109 «Resultando: Que el Señor Fiscal ha remitido a este Tribunal Supremo, la denuncia formulada en escrito del 4 del corriente mes por Don Alejandro Durán Cantos, Farmacéutico y vecino de esta Corte, contra el Exmo. Señor Don Galo Ponte y Escartin, Ex Ministro de Justicia y Culto, fundado en los siguientes hechos; que era de dominio público el procedimiento persecutorio seguido por la Dictadura y sus representantes gubernativos contra toda persona, sin respeto a su clase ni condición, cuando el sujeto perseguido no atendía sus indicaciones o mandatos; que la victima de esta denuncia era el Exmo. Señor Don Mariano Avellón y Quemada, fallecido siendo Presidente de Sala del Tribunal Supremo de Justicia, el día 5 de octubre pasado, que no fue excepción en el procedimiento dictatorial, de peor condición moral que el clásico del Santo Oficio...», Ibidem.

${ }^{110}$ Ibidem.
} 
Desaparecida la Dictadura, no cesan las arremetidas contra el ministro de la misma, Sr. Ponte. En este caso se producen en una reunión de la Comisión Permanente de la Diputación de Madrid, en la que uno de sus miembros, Sr. Cámara, en un breve discurso pronunciado efectúa graves denuncias contra el citado ministro. Destaca los nombramientos, efectuados por real orden, de oficiales de Sala para los Tribunales provinciales de lo Contencioso-administrativo ${ }^{111}$, considerados por el mismo como escandalosos, y solicita se dé cuenta al ministro del momento. Asimismo, otros diputados, estimaron que el asunto debería presentarse ante el Juez de guardia ${ }^{112}$.

De igual forma, encontramos duras críticas contra el modo de proceder del ministro, y el concepto patrimonialista de la justicia que impuso, hasta convertirla en el coto privado del mismo haciendo y deshaciendo a su antojo, en la obra de Quintiliano Saldaña. En la misma nos presenta un cuadro que no hace sino confirmar todo lo ya observado anteriormente ${ }^{113}$.

Si bien es cierto, que algunos de los episodios descritos pudiéramos considerarlos particulares e interesados, esgrimidos, en definitiva, por personas contrarias al régimen imperante, y más concretamente contra su representante en el ámbito de los tribunales, no es por ello menos cierto que aun incluso en aquellos otros en los que se loa la figura del Sr. Ponte, no dejan de resaltarse las acciones despóticas llevadas a cabo por el mismo, ya fueren de inspiración propia u obligado por las circunstancias o por el gobierno del que formaba parte «Nosotros que en muchas ocasiones (y no tantas como hubiéramos querido) hemos tenido que mantener criterios opuestos a la actuación del último ministro de Justicia y Clero, no queremos dejar de rendirle hoy

${ }^{111}$ El citado diputado, según afirma, se ve obligado a denunciar dichos asuntos considerados escandalosos. «Estos nombramientos fueron hechos por el ex ministro de la dictadura Sr. Ponte, que designó a varios funcionarios, y entre ellos a una señorita, que cobra un sueldo sin que nunca haya intervenido en la tramitación de los expedientes, que son despachados por oficiales de Audiencia... Ninguno de los nombrados reúne condiciones legales, ni siquiera la de la edad, pues se ha de tener veinticinco años, y se ha dado el caso de a que uno de ellos, precisamente sobrino del Sr. Ponte, tuvieron que pedirle que se vistiera de largo para asistir a la toma de posesión, pues no tenía ni quince años», en El Heraldo de Madrid, 3 de abril de 1930.

112 Ibidem.

113 «Convertir el escalafón de la Judicatura y la Magistratura en un teclado de favoritismo; ocultando las vacantes, para que no puedan solicitarlas los que desbordan de méritos; usando y abusando de los ascensos por elección; flagelando con postergaciones, por causas silenciadas; humillando a tres magistrados de territorial, al verse presididos por uno de provincial; reservando las plazas de Madrid y Barcelona para que sean detentadas por sus amigos (ahora, ex amigos); rompiendo la ecuación, tradicional y legal entre el cargo y la categoría, modo de aupar a los suyos -jueces de entrada- hasta los Juzgados de término, y, en una palabra revirtiendo a manos del ministro -como en los peores tiempos- todo lo concerniente al personal de Justicia... Someter a jueces de carrera, jueces de Primera Instancia e instrucción, a la secreta vigilancia humillante el cabo de la Guardia Civil del puesto de su partido y de la policía de trenes... Entregar de nuevo la Justicia municipal a las querellas de los partidos, convertida en ciego instrumento político... Haber arrebatado a la digna Magistratura y a la Judicatura españolas, la sagrada investidura de la inamovilidad... (De aquella humosa gasconada: «la verdadera revolución judicial» solo se percibieron los gases), en op. cit., pp. 47-50. 
un homenaje, que nos parece obligado en términos de lealtad $»^{114}$. Sin dirigir sus dardos contra la persona del ministro, no dejan de recordar algunas de las medidas que se adoptaron durante su mandato y que incidieron negativamente en esa independencia del Poder Judicial, tan cacareada por el poder político ${ }^{115}$.

Estas últimas reflexiones, junto a las anteriormente expuestas, que individualmente no resultarían de suficiente entidad para llegar a planteamientos definitivos, nos permiten del análisis de su conjunto, al que añadiremos un nuevo elemento, como es la propia obra legislativa promulgada durante su mandato, esbozar una idea, creo que, al menos aproximada, de la situación por la atravesó la independencia del Poder Judicial en el transcurso de los años 1926-1930, bajo el gobierno de la Dictadura de Primo de Rivera.

En base a todo ello, creo que se pueden deducir las siguientes:

\section{Conclusiones}

De la propia exposición del desarrollo normativo que se produce en este periodo, se puede colegir claramente la intención progresiva del ejecutivo de poner fin a los destellos de independencia del Poder Judicial que se habían ensayado en la etapa anterior (1923-1926), para ir arrebatando e incorporando al Ejecutivo todas aquellas funciones que, al menos desde el punto de vista de la legalidad, nos habían permitido hablar, de uno de los momentos de la historia de España, en la que la Independencia Judicial había alcanzado mayores cotas, y todo ello, como ya estábamos acostumbrados, manteniendo en sus grandes discursos, lógicamente vacuos de contenido, sus grandes proclamas sobre la independencia de los jueces.

La anterior afirmación abarca a todos los ámbitos de la administración de justicia. Desde el momento en que el Ministro designa a los miembros de la cúpula del Poder Judicial, quienes a su vez, nombran a los jueces inferiores, difícilmente podemos hablar de una autonomía de los mismos. Si a ello añadimos las reformas referentes a la suspensión de las sentencias firmes de la Sala Tercera del Tribunal Supremo y Tribunales provinciales contencioso-administrativos, la suspensión de la inamovilidad de los jueces, la competencias atribuidas al Jefe de la Sección de Justicia, Culto y Asuntos generales del Ministerio de Justicia en los informes sobre nombramientos, y el cese y nuevos nombramientos de los Jueces y Fiscales municipales, con las instruc-

\footnotetext{
${ }^{114} \mathrm{El} \mathrm{Sol}, 4$ de febrero de 1930.

115 «... el Sr. Ponte... se sumó a la obra dictatorial animado — no puede dudarse — de móviles desinteresados y patrióticos. Y como una dictadura vive, por naturaleza, en desarmonía con el Derecho, el Sr. Ponte hubo de pasar por la amargura de que se declarase la ineficacia de las sentencias del Tribunal Supremo, de que se decretase la amovilidad de jueces y magistrados, de que se destituyese sin razón y sin expediente a magistrados de dignidad indiscutible, de que volviese a manos del ministro todo lo concerniente al personal de la Justicia, de que se hiciese partidista la justicia municipal, de que se violase la autonomía de los Colegios de Abogados... Fácil es comprender lo que con todas estas determinaciones dictatoriales habrá padecido el espíritu ulquérrimo del titular de la cartera de Justicia», en Ibidem.
} 
ciones oficiosas publicadas por el Ministro, es evidente que la administración de justicia se ha convertido en apéndice del Ejecutivo.

La nueva situación reflejada expresamente en las disposiciones legales, no deja lugar a dudas, sobre el claro retroceso que supone en la autonomía de los jueces, con respecto al periodo correspondiente a los inicios del directorio militar. Retroceso que se podría explicar por las propias connotaciones del régimen político imperante. El dictador, Primo de Rivera, en su labor mesiánica, propia de los dictadores, llega al poder con el propósito de acabar con todos los errores cometidos por los gobiernos anteriores y salvar a la Patria de los mismos, pero la propia personalidad arbitraria del dictador, el ejercicio de ese poder, y la pérdida de apoyos al gobierno que se va produciendo como consecuencia del alargamiento, de lo que un principio, era una solución transitoria, va generando unos gobernantes cada vez más encerrados en sí mismos, y cuya supervivencia está sometida a un control mayor de todos los resortes del poder.

Esta misión, en lo que se refiere a los asuntos de justicia, no va ser desarrollada por un militar, sino que la va a protagonizar, un propio miembro de la carrera judicial, como es el Ministro Ponte Escartín. Persona controvertida ${ }^{116}$, que con sus ínfulas de lograr una verdadera revolución en la administración de justicia, va a certificar la defunción de lo que, en un principio, parecía ser una etapa de un cierto avance en el largo camino de la autonomía judicial.

El magistrado Ponte Escartín, no solo se encargará de crear un microcosmos normativo en el que el mismo se constituye en el principal eslabón, sino que, como hemos tenido ocasión de examinar, en las raras ocasiones en las que él podía sentirse mínimamente contestado, respondió con una actitud despótica, propia de quien se considera el máximo y único valedor de una administración de justicia justa, en la que los conceptos justicia y equidad se identificaban con su percepción subjetiva de los mismos; lo que intenta, en todo momento, acreditar con manifestaciones demostrativas

\footnotetext{
116 «De las restantes figuras del gobierno, en cambio, sí que puede decirse, como lo hizo el Duque de Maura que "tenían un nivel inferior al medio de los gobiernos constitucionales». Tal es el caso de Ponte o Callejo, cuya labor en Justicia o Instrucción atrajo fuertes protestas contra el régimen”, en X. Tusell Gómez, op. cit., p. 193. Especialmente crítico con la figura del Ministro es Salazar Alonso, de quien recojo a continuación algunos de sus pronunciamientos, totalmente definitorios de la consideración que le profesaba: «Así su paso por el Ministerio se aprecia entre audacias e improvisaciones, con la huella constante de su tosquedad, con el desprecio por los magistrados, con el afán torpe de ofender siempre. Fue altivo para sus subordinados. Sumiso y complaciente con Primo de Rivera, que le ordenaba desdeñoso y le tenía lastima por su servilismo», en op. cit., pp. 86 y 87 . También se pronuncia sobre la figura del Ministro Quintiliano Saldaña, quien aun reconociendo su acceso al cargo por méritos propios «Y yo, siempre en mi celo por evitar errores eventuales de la Historia futura, he de consignar que don Galo Ponte fue ministro por méritos propios — no por méritos de guerra—», para más tarde, considerarle el artífice de los recortes operados en la independencia del Poder Judicial, «Pero yo no puedo evitar que - un día - diga la Historia, con estas o parecidas palabras: al autorizar aquellos Decretos, el ministro Ponte, miembro de la Magistratura, por ser amigo del César, entregó a Cristo, que es la Justicia civil, y, desde aquel día, el ministro Ponte dejó de ser amigo del Poder civil», en op. cit., pp. 33 y 34 y 46-51.
} 
de los buenos propósitos que presiden sus actuaciones, o buscando la aceptación y justificación de las mismas de forma reiterada.

En definitiva, los aires renovadores que inspiraron las primeras medidas adoptadas por el Directorio, irán perdiendo este carácter con el transcurso del tiempo, acentuándose de manera explícita y rotunda a partir del año 1926, momento, en el cual, ya no va a ser un militar el que dirija los asuntos de justicia, sino que será un miembro de la propia magistratura. De nuevo aparecen truncados los propósitos de lograr un Poder Judicial independiente, para retornar a la realidad que había caracterizado la historia judicial de nuestro país.

No debemos, ni podemos concluir estas últimas reflexiones sin mencionar el papel jugado por los otros protagonistas de esta relación, como son los propios magistrados y jueces. De nuevo tendremos que admitir, una falta consistente y generalizada de respuesta por parte de estos últimos y especialmente de la cúpula judicial, ante las medidas gubernamentales. Falta de respuesta que se podría justificar por las expresas limitaciones impuestas por el propio estatuto de la carrera, pero sin olvidar, asimismo, una actitud conservadora de la cúpula judicial, de una parte, y de otra, un comportamiento interesado y a la vez comprensible de los miembros de la judicatura, quienes eran conscientes de que una respuesta mínimamente crítica de las actuaciones gubernamentales, podría constituirse en un claro freno para progresar en la carrera. Esta es la razón de que las únicas contravenciones a las medidas del ejecutivo procedieran, la mayor de parte de las veces, de los jueces inferiores, quienes carecían de tales aspiraciones, pero que resultaron arrancadas de cuajo, en estos casos, con las sucesivas destituciones adoptadas por el ejecutivo, así como con las instrucciones aconsejadas a seguir por el mismo para las nuevas designaciones. Todo ello, nos permite afirmar, la escasa respuesta, al menos, generalizada de los miembros de la magistratura, explicable además, tal y como señala muy acertadamente Montero Aroca, por la atmosfera en que se veían inmersos los mismos, lo que provocaba que asumieran como normal el respeto hacia los superiores y aceptaran su jerarquía de valores ${ }^{117}$.

\footnotetext{
${ }^{117}$ Quien, además, observa una cierta normalidad en tal actitud, en base a los siguientes planteamientos: "Si en la sociedad en general, el crítico o el original, la persona que se siente capaz de pensar por sí misma en contra de lo establecido, representa siempre una minoría, no hay razones para esperar que en la carrera judicial debiera ser distinto", en op. cit., pp. 107 y 108. Hay otros autores, como es el caso de A. Delgado Curto, quien defiende la existencia de observaciones "de forma comedida y respetuosa" dirigidas por la Carrera Judicial al Dictador, aunque no llegaran a exteriorizarse, en "Sobre la Administración de Justicia", Revista de los Tribunales, tomo LXV, nº 36-37, 1931, p. 515. En parecidos términos se pronuncia E. Pedraz Penalva, op. cit., p. 88.
} 